\title{
PERAN PENDEKATAN STUDENT CENTER LEARNING DALAM PROSES PEMBELAJARAN DI PRODI D-III KEPERAWATAN POLTEKKES KEMENKES BENGKULU
}

\author{
Pauzan Efendi, S.Pardosi
Politeknik Kesehatan Kementerian Kesehatan Bengkulu, Jurusan Keperawatan, Jalan Indragiri Nomor 03 Padang Harapan Kota Bengkulu jmkbengkulu@gmail.com

\begin{abstract}
Abstrac : Student Centre Learning (SCL) is a learning strategy that puts students as learners active and independent, with a psychological condition as an adult learner, are entirely responsible for learning, as well as being able to learn beyond the classroom (Harsono, 2008). The application of learning methods SCL on CBC be separate stimulus for students, because of changes in various factors, both in the learning objectives, learning targets, and the role of students in the learning process. The purpose of research is to know the description SCL's implementation approach at D III Nursing Programs Bengkulu Poltekkes $\mathrm{MoH}$ in accordance with operational guidelines, find a picture of the impact of the implementation of the SCL approach to students and lecturers as well as know the description of perception of students and lecturers of the implementation of the SCL approach. The results of observation curriculum and kaldek and good interviews with faculty and learners obtained the subject states have implemented learning system with subjects integrated with the system block and method of approach SCL through CBL, CL, CI, SGD and others in order to subject more akatif and independent in the learning process. The subjective perception of both lecturers as facilitators and subject as learners have the same perception that the SCL method is able to activate and independence. Methods of SCL is a learning strategy that puts students as active and independent learners, faculty and partners act as a facilitator of learning. On learning outcomes when viewed with the value, performance approach methods SCL in the study program diploma three Nursing Bengkulu has not shown any significant improvement, however, evaluation of learning outcomes to be especially helpful personal development both lecturers as facilitators and learners in achieving the learning objectives appropriate competencies expected. SCL expected learning method is not only a major impact on students but also requires a great contribution of lecturers and educational facilities. It takes a number of lecturers and adequate facilities for learning effectiveness can be fulfilled with the SCL method. Besides the ability of the entire faculty are similar in facilitating the learning process is very important that all students obtain a similar learning experience as well.
\end{abstract}

Keywords: Nursing, Student Center Learning

\begin{abstract}
Abstrak : Student Centre Learning (SCL) merupakan strategi pembelajaran yang menempatkan mahasiswa sebagai peserta didik yang aktif dan mandiri, dengan kondisi psikologik sebagai adult learner, bertanggung jawab sepenuhnya atas pembelajarannya, serta mampu belajar beyond the classroom Penerapan metode pembelajaran SCL pada KBK menjadi stimulus tersendiri bagi mahasiswa, karena adanya perubahan di berbagai faktor, baik dalam tujuan pembelajaran, target pembelajaran, serta peran mahasiswa dalam proses pembelajaran. Tujuan penelitian ini untuk mengetahui gambaran pelaksanaan implementasi pendekatan SCL pada D III Keperawatan Bengkulu Jurusan Keperawatan Poltekkes Kemenkes sesuai dengan pedoman pelaksanaannya, mengetahui gambaran dampak implementasi pendekatan SCL terhadap mahasiswa dan dosen pengajar serta mengetahui gambaran persepsi mahasiswa dan dosen pengajar terhadap implementasi pendekatan $S C L$. Hasil observasi kurikulum dan kalender akademik serta wawancara baik dengan dosen dan peserta didik didapatkan subjek menyatakan telah
\end{abstract}


melaksanakan system pembelajaran dengan mata kuliah terintegrasi dengan sistim blok dan metoda pendekatan SCL melalui Cbl,CL,CI,SGD dan lain-lain dalam rangka subjek lebih aktif dan mandiri dalam proses pembelajaran. Persepsi subjek baik dosen sebagai fasilitator dan subjek sebagai peserta didik mempunyai persepsi yang sama bahwa metoda SCL mampu mengaktifkan dan kemandirian serta membelajarkan dengan baik. Metoda SCL merupakan strategi pembelajaran yang menempatkan mahasiswa sebagai peserta didik aktif dan mandiri, dosen berperan sebagai fasilitator dan mitra pembelajaran. Terhadap hasil belajar bila dilihat dengan nilai, capaian pendekatan metoda SCL di program studi diploma tiga Keperawatan Bengkulu belum menunjukan perbaikan berarti, namun demikian evaluasi hasil belajar dirasakan sangat membantu pengembangan diri baik dosen sebagai fasilitator maupun peserta didik dalam mencapai tujuan pembelajaran sesuai kompetensi yang diharapkan. Diharapkan Metode pembelajaran SCL tidak hanya memberikan pengaruh yang besar pada mahasiswa tapi juga membutuhkan kontribusi yang besar dari dosen dan sarana pendidikan. Dibutuhkan jumlah dosen dan fasilitas yang memadai untuk dapat terlaksanakan efektifitas pembelajaran dengan metode SCL. Selain itu kemampuan seluruh dosen yang setara dalam memfasilitasi proses pembelajaran sangat penting agar semua mahasiswa memperoleh pengalaman belajar yang setara pula.

Kata kunci: Student Center Learning, Perawat

Kurikulum perguruan tinggi di Indonesia menerapkan kurikulum berbasis kompetensi (KBK) yang bertujuan meningkatkan kompetensi peserta didik secara menyeluruh. Mahasiswa tidak hanya dididik untuk pintar (mengetahui sesuatu), namun juga dapat menerapkan kompetensinya serta bersosialisasi dengan baik dalam kehidupan sehari hari. Proses pembelajaran dalam kurikulum berbasis kompetensi menggunakan metode pembelajaran student centered learning (SCL) (Sub Direktorat KPS, 2008).

SCL mengutamakan pengembangan kreativitas, kapasitas, kepribadian, dan kebutuhan mahasiswa, serta mengembangkan kemandirian dalam mencari dan menemukan pengetahuan. Metode pembelajaran yang dapat dipilih untuk pelaksanaan pembelajaran mata kuliah antara lain diskusi kelompok, simulasi, studi kasus, pembelajaran kolaboratif, kooperatif, berbasis proyek, berbasis masalah, atau metode pembelajaran lain, yang dapat secara efektif memfasilitasi pemenuhan capaian pembelajaran lulusan (PERMENDIKBUD No. 49 tahun 2014).

Poltekkes Kemenkes Bengkulu Jurusan DIII Keperawatan telah mengenalkan KBK pada tahun 2008, tetapi metode pembelajarannya belum menggunakan sistem SCL, masih banyak menggunakan eacher centered learning (TCL). Sistem pembelajaran SCL mulai diterapkan di Jurusan
DIII Keperawatan pada pada tahun akademik 2014/2015. Penerapan ini menyebabkan tarjadinya perubahan pusat pembelajaran, dari TCL atau berpusat pada dosen ke SCL atau berpusat pada mahasiswa.

Penerapan metode pembelajaran SCL pada KBK menjadi stimulus tersendiri bagi mahasiswa, karena adanya perubahan di berbagai faktor, baik dalam tujuan pembelajaran, target pembelajaran, serta peran mahasiswa dalam proses pembelajaran. Salah satu peran dari mahasiswa dalam pembelajaran SCL adalah mahasiswa secara aktif mengembangkan pengetahuan, keterampilan, aktif, serta mengembangkan karekter dirinya (Sub Direktorat KPS, 2008). Melalui SCL mahasiswa dituntut lebih pandai mengatur waktu, aktif melakukan diskusi baik di dalam maupun di luar kelas, mencari bahan literatur untuk diskusi, membuat makalah dan slide presentasi atau mempersiapkan roleplay. Diluar aktivitas belajar, mahasiswa juga tidak terlepas dari kebutuhan aktivitas lain, seperti bekerja atau aktif dalam organisasi di kampus. Tidak jarang dengan semua tuntutan tersebut membuat mahasiswa kewalahan dengan tugas dan kegiatan di kampus (Visaningrum, 2011 ; Manggarsari, 2012).

Penelitian, Manggarsari (2012) menginformasikan bahwa persepsi mahasiswa Program Sarjana Keperawatan Universitas 
Indonesia terhadap penerapan collaborative learning dan problem based learning pada KBK. Dari 107 mahasiswa 51,4\% mempunyai persepsi positif, dan $48,6 \%$ mempunyai persepsi negatif terhadap penerapan collaborative learning dan problem based learning pada KBK. Mahasiswa yang mempunyai respon positif mempersepsikan bahwa pembelajaran dalam sistem KBK sudah cukup baik karena meningkatkan kemampuan lisan, tulisan, berpikir kritis dan peningkatan motivasi pencarian sumber informasi. Mahasiswa yang mempunyai respon negatif mempersepsikan pembelajaran KBK menjadi stresssor utama karena banyaknya jumlah tugas yang harus di selesaikan, tingkat kesukaran tugas, dan kurangnya umpan balik.

Tuntutan internal maupun ekternal dari kehidupan akademik dapat memberi tekanan yang melampaui batas kemampuan mahasiswa akan menyebabkan over-load. Hal ini akan mengakibatkan terjadinya distress dalam bentuk kelelahan fisik atau mental, daya tahan tubuh menurun, dan emosi yang tak terkendali. Stress yang berkepanjangan yang dialami oleh individu dapat mengakibatkan penurunan kemam-puan untuk beradaptasi terhadap stress. Kondisi tersebut dapat memicu timbulnya masalah kesehatan pada individu. Peningkatan stress akademik akan menurunkan kemampuan akademik yang berpengaruh terhadap indeks prestasi. Beban stress yang dirasa terlalu berat dapat memicu gang-guan memori, konsentrasi, penurunan ke-mampuan penyelesaian masalah dan kemampuan akademik (Goff A.M, 2011 ; Purwati, 2012).

Susi Purwati, (2012) menginformasikan bahwa melalui pembelajaran SCL tingkat stress akademik pada mahasiswa regular program sarjana Universitas Indonesia. Dari 104 mahasiswa, teridentifikasi memiliki tingkat stres akademik sedang $(43,3 \%)$ dan mengunjungi pusat pelayanan kesehatan dalam satu bulan terakhir $(41,3 \%)$. Hasil tersebut menunjukkan terdapat korelasi positif antara stress akademik dengan mahasiswa, semakin tinggi tingkat stres akademik yang dialami, maka semakin se- ring mengunjungi pusat pelayanan kesehatan.

Beban tugas akademik yang dirasakan mahasiswa sebagai suatu tugas yang berat, akan mengakibatkan aktifnya jalur neuralendokrin dan merangsang sekresi hormon stress yang mengakibatkan pembuluh darah mengalami vasokontriksi. Terutama pembuluh darah kranial yang mengakibatkan respon nyeri pada bagian kepala (Sherwood, 2001 ; Purwati, 2012). Rasa nyeri tersebut sebagai bentuk kom-pensasi terhadap faktor lingkungan. Stressor yang tidak dapat dihentikan, maka dapat mengakibatkan mahasiswa kelelahan dan berakhir dengan gangguan kesehatan pada mahasiswa (Purwati, 2012).

Kelelahan yang terjadi pada mahasiswa mengakibatkan turunnya produktifitas dalam belajar maupun aktifitas pribadi (Friedberg, 1960 ; Rumiani, 2006 ). Perasaan kelelahan akan membuat kehilangan motivasi dalam melakukan aktivitasnya seharihari karena banyaknya stresssor yang diterima. Kondisi ini rentan untuk membuat mahasiswa melakukan prokrasti-nasi akademik (menunda kegiatan akademiknya). Prokrastinasi akademik ditandai dengan kelambanan, keterlambatan menghadiri kuliah, terlambat dalam menyelesaikan tugas hingga menunda belajar untuk ujian (Rizvi dkk,1997; Rumiani, 2006 ).

Penelitian yang dilakukan di Brazil oleh Camila et al (2010) menginformasikan bahwa kelelahan di kalangan mahasiswa sarjana keperawatan. Dari 189 mahasiswa, didapatkan $83,5 \%$ mahasiswa mengalami kelelahan dengan 59,8\% mengalami kelelahan tingkat sedang. Penyebab utama kelelahan adalah kegiatan akademik.

Menurut Weimar (2002) dalam Al zajdali, ada lima kunci standar yang harus dipertimbangkan oleh institusi untuk dapat melaksanakan SCL yaitu mahasiswa harus lebih bersemangat dikelas,lebih demokratis dan terebas dari stress, kontent yang digunakan harus membuat mahasiswa berfikir pertanyaan yang besar, tidak hanya sekedar menerima teori teori saja, Dosen harus bisa menjadi fasilitator dari pada menjadi diktator, mahasiswa harus menjadi lebih ber- 
tanggung jawab terhadap pembelajaran dirinya sendiri dan lebih sadar terhadap kelemahan dan kekuatannya sendiri, dan standar terakhir adalah metode evalusi yang lebih dari pada pemberian angka saja.

Hasil penelitian Rahmini (2007) yang mengunakan pendekatan SCL pada program pendidikan farmasi menemukan adanya peningkatan kemampuan mahasiswa dalam hal critical thinking, metacognitive self-regulation, and self efficacy. (Al zajdali). Kramer et al. (2007) juga menemukan hasil yang sama ketika menerapkan $\mathrm{SCl}$ pada mahasiswa terapi okupasi. Selain itu (Kramer et al., 2007) juga mengatakan SCL sangat membantu dosen dalam meningkatkan kreatifitasnya. SCL telah menunjukkan suatu perubahan dalam perilaku mengajar dosen baik dalam hal area subjek, peren-anaan, proses mengajar, manajemen kelas, komunikasi dan keterampilan evaluasi.

Hasil penelitian Yilmaz (2009) di Tur$\mathrm{ki}$, menemukan system pendidikan yang kaku, terpusat dan terpadu menyebabkan implementasi SCL hampir tidak mungkin dilakukan. Selain itu institusi pendidikan tidak memberikan pendidikan yang diperlukan untuk meningkatkan ke-mampuan dosen dalam melaksanakan pendekatan SCL. Tambahan lagi dosen menemukan berbagai masalah diantaranya kesulitan dalam merubah kerangka berfikir pendidikan dari top-down menjadi bottom-up, kesulitan dalam menerima peran sebagai teman pembelajar, pemandu dan fasilitator, yang berpusat pada mahasiswa tidak lagi pada apa yang dosen berikan.

Program studi Keperawatan Poltekkes Kemenkes Bengkulu adalah salah satu institusi pendidikan kesehatan yang mulai menggunakan kurikulum KBK dengan pendekatan SCL pada tahun 2014. Jurusan Keperawatan memiliki tiga program studi dimana masing masing prodi memiliki mahasiswa lebih kurang 180-240 mahasiswa dan lebih kurang 8-10 orang dosen pengajar. Hasil studi pendahuluan yang dilakukan oleh peneliti, melalui wawancara pada 10 orang mahasiswa yang diterapkan pendekatan SCL tentang persepsi maha-siswa terhadap SCL didapatkan 2 orang mahasiswa menyatakan bingung dengan metode tersebut, 3 siswa menyatakan kelelahan dengan diterapkan metode SCL karena terlalu banyak tugas, 4 orang mahasiswa menyatakan senang dengan metode SCL karena mereka merasa lebih bebas dan lebih aktif dalam proses pembelajaran dan 1 orang mengatakan tidak ada bedanya antara SCL dengan metode TCL.

Berdasarkan hasil studi pendahuluan didapatkan bahwa dosen didapatkan 3 orang dosen mengatakan bahwa metode SCL tidak hanya melelahkan mahasiswa tapi juga melelahkan dosen karena dosen harus masuk kelas setiap hari baik dalam pembelajaran klasikal maupun dalam pembelajaran colaborative dan small group. 2 orang dosen mengatakan senang dengan SCL karena dosen tidak perlu terlalu sering menyiapkan materi mengajar tetapi hanya perlu membuat kunci kunci penting saja dalam topik pembelajaran karena selebihnya mahasiswa yang akan mencari sendiri untuk pemahaman terhadap topik tersebut. 3 orang dosen mengatakan kerepotan dengan system $\mathrm{SCl}$ karena harus lebih sering membaca meningkatkan pengetahuan dan keterampilannya sehingga dapat menjadi fasilitator yang dapat memandu mahasiswa dalam pemahaman topik-topik pembelajaran. Tujuan penelitian mengetahui gambaran implementasi pendekatan Student Centre Learning di Prodi Keperawatan Poltekkes Kemenkes Bengkulu

\section{BAHAN DAN CARA KERJA}

Rancangan penelitian deskriptif dengan pendekatan kualitatif dengan menggunakan metode survey/wawancara mendalam. Penelitian ini dilakukan di Jurusan Keperawatan Poltekkes kemenkes Bengkulu dari bulan Februari 2015 s/d September 2015. Subjek penelitian diambil secara purposive dengan jenis criterion sampling yaitu dosen dan mahasiswa yang terlibat langsung dalam proses pembelajaran dengan metoda SCL di Diploma Tiga Keperawatan Bengkulu. Teknik pengumpulkan 
data penelitian dilakukan melalui kuesioner dengan triangulasi dengan indeph interview, sebagai pendukung digunakan observasi dan analisis dokumen akademik termasuk hasil evaluasi beberapa mata kuliah. Analisis data dalam penelitian ini bersifat deskriptif dengan pendekatan kualitatif. Analisis data dilakukan secara terus menerus sejak awal hingga akhir penelitian.

\section{HASIL}

Tabel 1. Karateristik Responden Penelitian

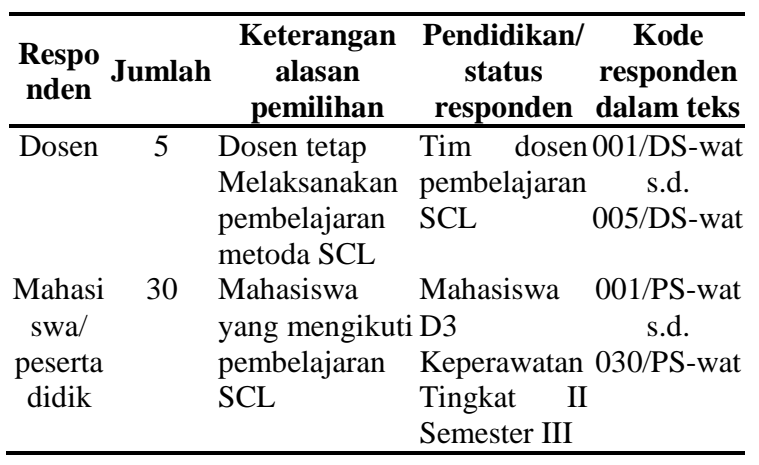

\section{Gambaran pelaksanaan implementasi SCL}

Dari hasil wawancara terstruktur dan observasi subjek telah menjalankan proses pembelajaran dengan metoda SCL. Dosen sebagai fasilitator dan media pembelajaran, peserta didik sebagai subjek yang aktif dan mandiri sebagaimana tertera pada tabel 2 berikut.

Tabel 2. Pelaksanaan pembelajaran

\begin{tabular}{|c|c|c|}
\hline $\begin{array}{c}\text { Kaldek } \\
\text { semeste } \\
\mathrm{r}\end{array}$ & $\begin{array}{l}\text { Bentuk mata } \\
\text { kuliah }\end{array}$ & Metode dan pendekatan \\
\hline I & $\begin{array}{l}\text { Terintegrasi } \\
\text { /Blok }\end{array}$ & $\begin{array}{c}\text { SCL melalui; } \\
\text { CL,CbL,CI,DL,SDL,PjBL } \\
\text {,PBL/I }\end{array}$ \\
\hline II & $\begin{array}{c}\text { Terintegrasi/B } \\
\text { lok }\end{array}$ & $\begin{array}{c}\text { SCL melalui; } \\
\text { CL,CbL,CI,DL,SDL,PjBL } \\
\text {,PBL/I }\end{array}$ \\
\hline
\end{tabular}

Hasil observasi kurikulum dan kaldek serta wawancara baik dengan dosen dan peserta didik didapatkan subjek menyatakan telah melaksanakan system pembelajaran dengan mata kuliah terintegrasi dengan system blok dan metoda pendekatan SCL melalui Cbl, CL, CI, SGD dan lain-lain dalam rangka subjek lebih akatif dan mandiri dalam proses pembelajaran. Sebagaimana pernyataan subjek penelitian ;
"Implementasinya : setelah kontrak program, mahasiswa ditugaskan dengan tugas tertentu dalam beberapa kelompok kemudian diseminarkan, diskusi... dan penilaian didasarkan atas proses masing-masing individu_(Indepth 004/DS-wat)".

\section{Gambaran persepsi mahasiswa dan dosen terhadap pendekatan SCL}

Berdasarkan hasil wawancara didapat bahwa subjek menyatakan sudah memahami dan melaksanakan pembelajaran dengan metoda SCL dalam proses pembelajaran. Pelaksanaan sudah sesuai dengan panduan pembelajaran sebagaimana dinyatakan subjek;

"metoda SCL ini sangat efektif menurut saya_ karena didalam blok mata kuliah itu menyangkut pembelajaran keperawatan persistem tubuh__ mulai dari anatomi fisiologi, pemeriksaan, gawat darurat sudah ada dalam satu blok ini__ sehingga mahasiswa menjadi lebih mengerti dibandingkan dengan materi anatomi fisiologi yang terpisah___(Wawancara 023/PS-wat).

Pernyataan subjek sebagai peserta didik lain juga mendukung sebagaimana dinyatakan;

"metode SCL sangat bagus diterapkan__karena memotivasi untuk belajar aktif, mengharuskan disiplin sehingga dapat terbiasa dan memanfaatkan waktu le-bih efektif dan efisien__ mahasiwa lebih mandiri_ bebas menyampaikan pendapat__ lebih dapat memahami maeri_ (wawancara 018/PS-wat).

Tabel 3. Persepsi subjek terhadap pendekatan SCL

\begin{tabular}{|c|c|c|c|c|}
\hline \multirow{2}{*}{\multicolumn{2}{|c|}{$\begin{array}{l}\text { Metoda } \\
\text { pengumpula data } \\
\text { Wawancara } \\
\text { terstruktur/kuesion } \\
\text { er }\end{array}$}} & \multirow{2}{*}{\multicolumn{2}{|c|}{$\begin{array}{ll}\begin{array}{l}\text { Persepsi } \\
\text { SCL }\end{array} & \text { terhadap } \\
\text { Paha } & \text { Mengetahui } \\
\mathrm{m} & \text { tapi subjek } \\
& \text { sulit } \\
& \text { menjelaska } \\
& \mathrm{n} \\
\end{array}$}} & \multirow{2}{*}{ Standar } \\
\hline & & & & \\
\hline Dosen & $\begin{array}{l}\text { 001/DS } \\
\text {-wat } \\
\text { s.d. } \\
\text { 005/DS } \\
\text {-wat }\end{array}$ & $\mathrm{V}$ & & \\
\hline $\begin{array}{l}\text { Peserta } \\
\text { didik }\end{array}$ & $\begin{array}{l}\text { 001/PS- } \\
\text { wat } \\
\text { s.d. } \\
\text { 030/PS- } \\
\text { wat }\end{array}$ & $r$ & & \\
\hline
\end{tabular}


Dosen sebagai fasilitator juga telah memahami dan melaksakan proses pembelajaran dengan metode SCL, sebagaimana pernyataan subjek sebagai dosen.

\section{PEMBAHASAN}

\section{Gambaran pelaksanaan implementasi SCL}

Hasil observasi kurikulum dan kaldek serta wawancara baik dengan dosen dan peserta didik didapatkan subjek menyatakan telah melaksanakan system pembelajaran dengan mata kuliah terintegrasi dengan system blok dan metoda pendekatan SCL melalui Cbl, CL, CI, SGD dan lain-lain dalam rangka subjek lebih akatif dan mandiri dalam proses pembelajaran Pernyataan ini sesuai dengan subjek sebagai peserta didik dalam wawancara terstruktur;

"keuntungan : jadwal kuliah lebih teratur_gambaran tugas sudah Nampak_sudah diketahui jauh-jauh hari_adanya diskusi kelompok beberapa orang sehingga akan membuat mahasiswa lebih memahami materi dan lebih aktif__ (Wawancara 026/PS-wat)".

Hampir semua subjek penelitian menyatakan pelaksanaan metoda SCL telah dilakukan dalam proses pembelajaran dan sangat bermanfaat walaupun masih banyak kendala dan hambatan yang perlu dievaluasi. Sebagai hambatan antara lain dinyatakan subjek sebagai peserta didik ;

"kerugian: dari sisi keuangan karena metode ini tugas sangat banyak_ sehingga pengeluaranpun cukup banyak, __ tenaga pengajarnya kurang sehingga membagi waktu utuk kelompok kecil sedikit terganggu dan ruangan yang digunakan kurang__(Wawancara 028/PS-wat)".

\section{Gambaran persepsi mahasiswa dan dosen} terhadap pendekatan SCL

Persepsi subjek baik dosen sebagai fasilitator dan subjek sebagai peserta didik mempunyai persepsi yang sama bahwa metoda SCL mampu mengaktifkan dan kemandirian serta membelajarkan dengan baik. Hal ini sesuai dengan panduan pembelajaran dengan pendekatan SCL. Pernyataan ini sesuai dengan subjek sebagai peserta didik dalam wawancara terstruktur; "keuntungan : jadwal kuliah lebih teratur gambaran tugas sudah Nampak_ sudah diketahui jauh-jauh hari__ adanya diskusi kelompok beberapa orang sehingga akan membuat mahasiswa lebih memahami materi dan lebih aktif__ (Wawancara 026/PS-wat)".

Hampir semua subjek penelitian menyatakan pelaksanaan metoda SCL telah dilakukan dalam proses pembelajaran dan sangat bermanfaat walaupun masih banyak kendala dan hambatan yang perlu dievaluasi. Sebagai hambatan antara lain dinyatakan subjek sebagai peserta didik ;

"kerugian: dari sisi keuangan karena metode ini tugas sangat banyak_ sehingga pengeluaranpun cukup banyak, __ tenaga pengajarnya kurang sehingga membagi waktu utuk kelompok kecil sedikit terganggu dan ruangan yang digunakan kurang__(Wawancara 028/PS-wat)".

\section{Dampak Implementasi SCL terhadap Mahasiswa dan Dosen}

Metoda SCL merupakan strategi pembelajaran yang menempatkan mahasiswa sebagai peserta didik aktif dan mandiri, dosen berperan sebagai fasilitator dan mitra pembelajaran. Terhadap hasil belajar bila dilihat dengan nilai, capaian pende-katan metoda SCL di program studi diplo-ma tiga Keperawatan Bengkulu belum menunjukan perbaikan berarti, namun demikian evaluasi hasil belajar dirasakan sangat membantu pengembangan diri baik dosen sebagai fasilitator maupun peserta didik dalam mencapai tujuan pembelajaran sesuai kompetensi yang diharapkan. Dampak implementasi SCL yang positif dinyatakan subjek sebagai dosen sebagai berikut :

"dosen bias focus dengan tugas-tugasnya sebagai dosen dan beban kerja lebih ringan sebagai fasilitator__emampuan pesdik akan mudah dikontrol sehingga pesdik yang butuh eksktra perhatian bias dioptimalkan refrensi akan semakin ber-tambah dan wawasan pengetahuan sema-kin meluas__mahasiswa akan semain terampil dalam berkomunikasi__ namun disamping kelebihan ada "resiko penye-lenggaraan_ dibutuhkan SDM yang Pro-fesional dan memadai dengan jumlah rasio mahasiswa yang ada__ dibutuhkan fasili-tas ruangan 
tersendiri untuk setiap kelom-pok__fasilitas yang nyaman_ membu-tuhkan SOP dan Standar yang dipahami semua yang terlibat_(wawancara 004/DS-wat).

\section{KESIMPULAN}

Hasil observasi kurikulum dan kaldek serta wawancara baik dengan dosen dan peserta didik didapatkan subjek menyatakan telah melaksanakan system pembelajaran dengan mata kuliah terintegrasi dengan system blok dan metoda pende-katan SCL melalui Cbl,CL,CI,SGD dan lain-lain dalam rangka subjek lebih aktif dan mandiri dalam proses pembelajaran. Terdapat pedoman dan SOP yang sesuai dalam pelaksanaan implementasi pendekatan pembelajaran dengan metoda SCL.

\section{DAFTAR RUJUKAN}

Direktorat akademik (2008) Buku Panduan Pengembangan Kurikulum Berbasis Kompetensi Pendidikan Tinggi (Sebuah Alternative Penyusunan Kurikulum), Direktorat Jenderal Pendidikan Tinggi. Jakarta.

Hadi, Rahmini. 2007. Dari Teacher Centered Learning ke Student Centered Learning. Jurnal Pemikiran Alternatif Pendidikan vol. 12 no. $13: 408-419$

Harsono. 2008. Student Centered Learning di Perguruan Tinggi. Jurnal Pendidikan Kedokteran dan Profesi Kesehatan Indonesia vol. 3 no. 1

Manggasari. 2012. Persepsi Mahasiswa Keperawatan Universitas Indonesia Program Sarjana terhadap Penerapan Collaborative Learning dan Problem Based learning pada Kurikulum Berbasis Kompetensi. Fakultas Ilmu Keperawatan Universitas Indonesia. Depok.

Natoatmodjo, Soekidjo. 2010. Metodologi Penelitian Kesehatan. Jakarta : PT Asdi Mahasatya.
Terhadap hasil belajar bila dilihat dengan nilai, capaian pendekatan metoda SCL di program studi diploma tiga $\mathrm{Ke}$ perawatan Bengkulu belum menunjukan perbaikan berarti, namun demikian evaluasi hasil belajar dirasakan sangat membantu pengembangan diri baik dosen sebagai fasilitator maupun peserta didik dalam mencapai tujuan pembelajaran sesuai kompetensi yang diharapkan.

Hasil penelitian ini menambah wawasan tenaga pengajar dalam menerapkan pendekatan SCL dalam proses pembelajaran. Kemampuan sebagai pendidik harus ditingkatkan, dan semua tenaga pendidik seharusnya sebelum penetapkan sebagai dosen mendapatkan kesempatan magang klinik khusnya bagi pendidikan perguruan tunggi yang menyelenggarakan pendidikan teknis atau vokasional.

Peraturan Menteri Pendidikan dan Kebudayaan Republik Indonesia Nomor 49 Tahun 2014 Standar Nasional Pendidikan Tinggi.

Purwati, Susi. 2010. Tingkat Stress Akademik pada Mahasiswa Regular angkatan 2010 Fakultas Ilmu Keperawatan Universitas Indonesia. Fakultas Ilmu Keperawatan Universitas Indonesia. Depok.

Putri, Duhita Pangesti. 2008. Hubungan Faktor Internal dan Eksternal Kelelahan pada Pekerja Operator Alat Besar di PT Indonesia Power Unit Bisnis Pembangkitan Suralaya Periode Tahun 2008. Fakultas Kesehatan Masyrakat Universitas Indonesia. Depok.

Rumiani. 2006. Prokrastinasi Akademik Ditinjau dari Motivasi berprestasi dan stress mahasiswa. Jurnal psikologi universitas diponegoro vol. 3 no. 2.

Silpia dan Neviyarni. 2013. Faktor - Faktor Penyebab Rendahnya Prestasi Belajar Siswa. Jurnal ilmiah konseling vol. 2 : $225-230$

Wilmar et al. 2002. Burnout and Engagement in University Student. Journal of Cross Cultular Psychology vo. 33. No. 5 